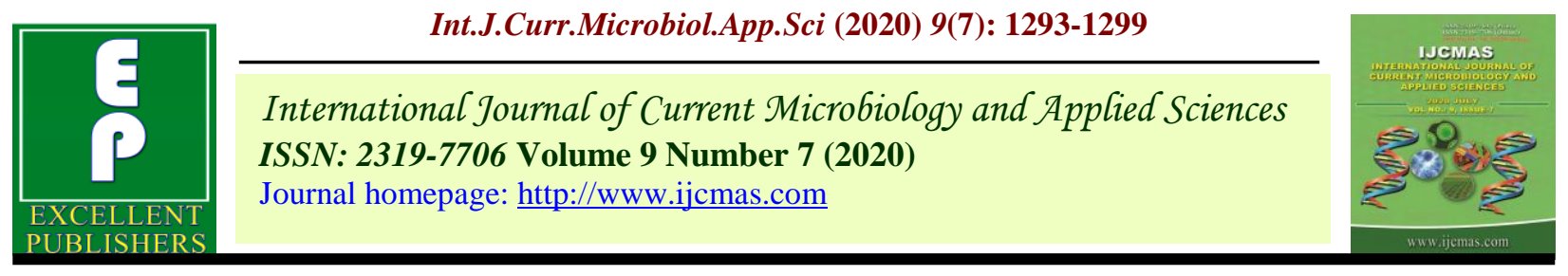

Review Article

https://doi.org/10.20546/ijcmas.2020.907.148

\title{
Spray Dried Fermented Milk Products
}

\author{
Kritika Rawat ${ }^{1}$, Anju Kumari ${ }^{*}$, Rakesh Kumar ${ }^{2}$ and Partibha ${ }^{1}$ \\ ${ }^{1}$ Centre of Food Science and Technology, ${ }^{2}$ Department of Microbiology, Chaudhary Charan \\ Singh Haryana Agricultural University, Hisar, Haryana, India 125004 \\ *Corresponding author
}

\begin{tabular}{|l|}
\hline K e y w o r d s \\
$\begin{array}{l}\text { Spray drying, Milk, } \\
\text { Fermentation, } \\
\text { Probiotics, Powder }\end{array}$ \\
\hline Article Info \\
\hline $\begin{array}{l}\text { Accepted: } \\
\text { 11 June } 2020 \\
\text { Available Online: } \\
\text { 10 July } 2020\end{array}$ \\
\hline
\end{tabular}

\section{A B S T R A C T}

Fermented milk products are perishable in nature. They possess lot many health benefits due to probiotic nature. Most of the fermented dairy products are available in liquid form that is highly perishable in nature. Spray drying technology presents a better, convenient and affordable method for preserving such products by enhancing their storability and making them shelf stable from a week to several months. The technology convert fermented milk products into powder form, which are stable, probiotic, easy to use, easy to transport, and is appropriate for solicitations in the food sector. The overall demand for probiotic dried fermented dairy products has improved in perspective of promptly developing market, corroborating the requirement for their significant production. Only a few spray dried fermented milk powders like Srikhand, Kefir, Yoghurt, Bifidus milk and cheese are reported, therefore, this review specifically provide a state of knowledge on the preparation of spray dried fermented milk powder.

\section{Introduction}

Lactic acid bacteria is prominently used to ferment food chiefly milk since time immemorial, which have occasioned to produce cultured dairy products with distinctive flavour which makes them divergent from core food (Amadoro et al., 2018). Along with the conservation and modification of nutrients of milk, fermentation complies the consumer with live and active probiotic cultures, when taken in passable amount confer health benefits (FAO/WHO, 2002). But these functional foods are highly perishable in nature (Shiby and Mishra, 2013). Their perishability is attributed to high production of lactic acid (Hati et al., 2019) which creates an acidic environment. Shelf life extension of most dairy products is done through pasteurization and chemical preservatives which affect viability of probiotics. Generally fermented 
milk products are stored in the refrigerator to extend their shelf life. Moreover, they also require refrigeration during transportation thereby increasing cost which may be costly especially to those in rural communities.

As a way of dealing with perishability of these products and reducing cost due to transport, spray drying has been employed in the drying of fermented milk products to make powders, which can be stored for longer periods at ambient temperatures (Costa et al., 2015). The dehydration of these products helps in stabilizing them for storage and later use (Schuck, 2016). Spray drying is preferred in dairy industry because of its less operational costs and more output (Wirjantoro and Phianmongkhol, 2009; Koc et al., 2014). It is a process through which liquid state of food is converted into solid state (powder), by spraying the liquid feed through nozzle or atomizer into a hot dried chamber (Friesen et al., 2019). This method causes minimal structural and functional changes in dairy food products (Gabites et al., 2010; Kumar et al., 2018). Masses of literature is available on spray dried milk powder, but very scarce compilation is available on spray dried fermented milk products like Srikhand, Kefir, Yoghurt, Bifidus milk and cheese powder (Fig. 1). This review offers update with specific reference to the spray dried fermented dairy products.

\section{Spray drying of fermented milk products}

Spray drying is used to dehydrate dairy products and its process conditions are directly associated with the production costs and value of the final product (Santos et al., 2018). Some researchers have recorded the success of spray dried fermented milk products (Kothakota et al., 2014, De, 1980). Inlet temperature, outlet temperature and speed of drying are crucial factors for continuous production of probiotic fermented dairy products (Gharsallaoui et al., 2007).

\section{Srikhand powder}

Srikhand is a semi-soft dairy product prepared commonly from buffalo milk Anagnostopoulos and Tsaltas, 2019; Tamang et al., 2020). During its preparation, the curd is drained, and then the solid mass obtained is called chakka. It is mixed with an adequate amount of sugar to obtain srikhand (Narayanan and Lingam 2013). In the process of making spray dried powder, the srikhand go through pre-treatment stages which involve homogenization and concentration. Mahajan et al., (1979) reported on spray dried srikhand powder in which homogenized slurry was adjusted to 35 percent total solid and spray dried at pre-determined inlet air temperature and outlet temperature i.e. 180$200^{\circ} \mathrm{C}$ and $100^{\circ} \mathrm{C}$ respectively. Storability of this powder is appraised over three months provided the product is packed in hermetically sealed containers.

\section{Kefir powder}

Kefir is fermented dairy product of North Caucasus Mountain, Eastern Europe and Russia produced chiefly from cow or sheep milk. Kefir milk is prepared by inoculating milk with kefir grains. These grains comprise of bacteria and yeast in a synergetic matrix. The following species of LAB and yeast which forms up the matrix: Acetobacter, Kluyveromyces marxianus, Lactobacillus, Leuconostoc, Lactococcus and Saccharomyces respectively (Anonymous 2009). An inlet air temperature, outlet temperature and feed temperature $\left(171^{\circ} \mathrm{C}\right.$, $60.5^{\circ} \mathrm{C}$ and $15^{\circ} \mathrm{C}$ ) were noted as most favourable for yoghurt powder (Koc et al., 2010) with respect to the survival probiotics; color, moisture and overall acceptability of powder. Atalar and Dervisoglu (2015), modelled and optimized spray drying of Kefir by means of response surface methodology and produced supreme quality powder as spray dried powder. 
If feed temperature, pump rate and inlet air temperature was in a range of $4-30^{\circ} \mathrm{C}, 120$ $180^{\circ} \mathrm{C}$ and $20-40 \%$ respectively, then maximum survival rates of probiotics, decreased moisture content of kefir powder was obtained. After spray drying the maximum survival rate was observed in Lactococci $8.51 \times 10^{3}$, Lactobacilli $9.54 \times 10^{2}$ and Leuconostoc $3.23 \times 10^{2}$. Teijeiro et al., (2018) described the effect of alteration in carriers during spray drying of traditional kefir. They observed a fewer viable count when kefir was dehydrated without carriers. Whereas, $9 \log$ CFU/g survival of LAB by using a carrier named skim milk however, when carrier medium was whey permeate then $8 \log \mathrm{CFU} / \mathrm{g} \mathrm{LAB}$ and $4 \log \mathrm{CFU} / \mathrm{g}$ yeast was obtained. In kefir powder when skim milk was used as carrier, then maximum probiotics survival was simulated under GI conditions and retained stable for minimum 60 days at $4{ }^{\circ} \mathrm{C}$. It was concluded that spray drying is an appropriate methodology to prepare kefir powder.

\section{Yogurt powder}

Yoghurt, similar to Indian curd prepared from whole milk. It is obtained after fermentation by two specific strains: Streptococcus thermophilus and Lactobacillus bulgaricus. The best spray dried optimized condition for yoghurt preparation was $15^{\circ} \mathrm{C}$ feed temperature, $171^{\circ} \mathrm{C}$ inlet air temperature and $60.5^{\circ} \mathrm{C}$ outlet temperature, respectively (Koc et al., 2010). Spray drying of Chakka (strained yoghurt) was reported by De and Patel (1989) who used $190^{\circ} \mathrm{C}$ and $95^{\circ} \mathrm{C}$ as inlet and outlet temperatures respectively. Prior spray drying yoghurt is churned to obtain a uniform mass followed by adjustment of the total soluble sugars (Kim and Bhowmik, 1995). According to Seshamamba et al., (2016) yoghurt with $25 \%$ TSS yield a high amount of powder and that when reconstituted there is little difference between the fresh and reconstituted yoghurt.
Basu and Athmaselvi (2018) developed spray dried curd powder with mango flavour. They observed that in high inlet temperature powder still had some viable count of probiotic microorganism and furthermore concluded if the particle size of powder is small then it results in poor flowability of powder. For preparation of sweetened yogurt powder inlet temperature of spray drier: 140$180^{\circ} \mathrm{C}$, rate of feed $0.3-0.6 \mathrm{~L} / \mathrm{h}$ and atomizers' pressure $500-1000 \mathrm{kPa}$ was studied (Seth et al., 2017a).

Yogurt powder exhibited negative correlation in reference to solubility and dispersibility with variations in inlet temperatures of spray drier and atomizers' pressure. Rate of feed of yogurt expressively affected the solubility of yogurt powder while, as the inlet temperature was raised simultaneously an increase in wetting time of powder was observed. A decrease in flow property and water activity of sweetened yogurt powder as inlet air temperature of spray drier and atomizers' pressure increased whereas, water activity increased with gradually increase in rate of feed. Under optimal conditions of spray drying (inlet air temperature $148^{\circ} \mathrm{C}$, feed rate $0.54 \mathrm{~L} / \mathrm{h}$, and atomization pressure $898 \mathrm{kPa}$ ), Seth et al., (2019) confirmed that a practically fair quality shelf-stable sweetened yoghurt powder can be manufactured. By spray drying a commercial drinkable yogurt with low water activity and total bacterial count of 8.48-8.90 $\log \mathrm{cfu} / \mathrm{g}$ was produced by Bater et al., 2019. In spray-dried yoghurt $S$. thermophilus showed better survival than Lactobacillus bulgaricus (Bielecka and Majkowska, 2000).

\section{Bifidus milk powder}

Bifidus milk is a product of milk fermentation by probiotic strain Bifidobacterium bifidum (BB). Selvamuthukumaran and Shukla (2016) supplemented milk with gelatin, monosodium glutamate and skim milk powder for increasing the concentration to desired levels 
(slurry) for manufacturing spray dried bifidus milk powder. Bifidus milk was spray dried with $175^{\circ} \mathrm{C}$ inlet and $65^{\circ} \mathrm{C}$ outlet air temperatures, respectively. The viable count of probiotic microorganism during spray drying was maximum when the inlet spray driers' temperature, bifidus milk concentration and inlet air pressure in spray drier chamber was $164^{\circ} \mathrm{C}, 25.62 \%$ of 2.5 $\mathrm{kg} / \mathrm{cm}^{2}$ respectively. Bifidus milk powder was shelf stable up to four months when stored under room temperature, with good overall acceptability after reconstitution to form bifidus milk.

\section{Cheese powder}

Lab scale spray driers were used for the manufacturing of cheese powder (Pisecky, 2005; Erbay and Koca, 2019). Gardiner et al., (2002) spray-dried probiotic milk powder at inlet and outlet temperatures of $175^{\circ} \mathrm{C}$ and $68^{\circ} \mathrm{C}$ with probiotic survival $(84.5 \%)$. Further they manufactured cheddar cheese by using this powder, having $1 \times 10^{9} \mathrm{cfu} \mathrm{g}^{-1}$ of $L b$. paracasei NFBC 338 Rif $^{\mathrm{r}}$ without adversely affecting the cheese quality. A successful trial was performed with pre-determined atomizers' pressure, inlet temperature and outlet temperature of spray drier chamber $\left(354 \mathrm{kPa}, 174^{\circ} \mathrm{C}\right.$ and $68^{\circ} \mathrm{C}$ ) to prepare cheese powder. Powder was observed to have bulk density $\left(252 \mathrm{~kg} / \mathrm{m}^{3}\right)$, fat $(40.7 \%)$, nonenzymatic browning (0.123 OD) and solubility index $(82.7 \%)$, respectively (Erbay et al., 2015). Erbay and Koca (2019), prepared cheese powder by incorporation of maltodextrin and whey to improve its physical properties. A decrease in volatile fatty acid was estimated during formulation of emulsion (9\%) and was highest after spray drying process $(53.5 \%)$. Sweet whey powder added to Danbo cheese prior spray drying resulted better solubility, small particle size and faster wettability properties (Da Silva et al., 2018).

\section{Challenges}

Spray drying of fermented milk products is tedious task due to its acidic $\mathrm{pH}$, which results adhesiveness in driers' chamber and makes difficulty in recovery of powder. Another drawback of spray drying fermented milk products is that products lose the key flavour components such as diacetyl in curd and acetaldehyde in yogurt. Spray drying process hinge on material concentration, feed rate, nozzle pressure, inlet and outlet air temperature which play a crucial role in probiotics' viability and cellular damage occurred due to thermal and dehydration stress during drying (Fu and Chen, 2011; Seth et al., 2017b). Survival rate of lactic acid bacteria is one of the major challenges to get probiotic dairy powder along with pleasant sensory characteristics.

In conclusion, spray drying method provides suitable and agreeable method to commercially manufacture fermented milk powders with lower cost, easy availability, easy to store, handle, transport and convenient to use. Powders available throughout year may be used in varied food preparations like an instant beverage and functional foods. For commercial utility of spray drying technology further research will be focused on standardization of the spray drying conditions for specific fermented milk products to retain their original nutritive, probiotic and sensorial characteristics.

\section{References}

Amadoro, C., Rossi, F., Pallotta, M.L., Gasperi, M., and Colavita, G. 2018. Traditional dairy products can supply beneficial microorganisms able to survive in the gastrointestinal tract. LWT-Food Science and Technology 93: 376-383.

Anagnostopoulos, D.A., and Tsaltas, D. 2019. 
Fermented Foods and Beverages. In Innovations in Traditional Foods (pp. 257-291). Woodhead Publishing.

Anonymous, 2009. Turkish food codex, fermented milk notification. Ankara: Resmi Gazete (in Turkish).

Atalar, I., and Dervisoglu, M. 2015. Optimization of spray drying process parameters for kefir powder using response surface methodology. LWTFood Science and Technology 60(2): 751-757.

Basu, A., and Athmaselvi, K.A. 2018. Characterisation of mango flavoured curd powder developed using spray drying technique. Journal of Dairy Research 85(2): 243-246.

Bater, C., Santos, M., Galmarini, M.V., Gómez-Zavaglia, A., and Chirife, J. 2019. Influence of different storage conditions on the performance of spray-dried yogurt used as inoculum for milk fermentation. Journal of Dairy Research 86(3): 354-360.

Bielecka, M., and Majkowska, A. 2000. Effect of spray drying temperature of yoghurt on the survival of starter cultures, moisture content and sensoric properties of yoghurt powder. Food/Nahrung, 44(4): 257 260.

Costa, S.S., Machado, B.A.S., Martin, A.R., Bagnara, F., Ragadalli, S.A., and Alves, A.R.C. 2015. Drying by spray drying in the food industry: microencapsulation, process parameters and main carriers used. African Journal of Food Science, 9(9).

Da Silva, D.F., Hirschberg, C., Ahrne, L., Hougaard, A.B., and Ipsen, R. 2018. Cheese feed to powder: Effects of cheese age, added dairy ingredients and spray drying temperature on properties of cheese powders. Journal of Food Engineering 237: 215-225.

De, A., and Patel, R.S. 1989. Technological aspects of manufacturing chakka powder. Japanese Journal of Dairy and Food Science 38(4): 169-174.

De, S., 1980. Outlines of dairy technology. Outlines of dairy technology.

Erbay, Z., and Koca, N. 2019. Effects of using whey and maltodextrin in white cheese powder production on free fatty acid content, nonenzymatic browning and oxidation degree during storage. International Dairy Journal 96:1-9.

Erbay, Z., Koca, N., Kaymak-Ertekin, F., and Ucuncu, M. 2015.Optimization of spray drying process in cheese powder production. Food and Bioproducts Processing 93: 156-165.

FAO/WHO. 2002. Guidelines for the evaluation of probiotics in foods. Food and Agriculture Organization of the United Nations and World Health Organization Expert Consultation Report (online).

Friesen, D.T., Newbold, D.D., Baumann, J.M., Dubose, D.B., and Millard, D.L. 2019. U.S. Patent No. 10,300,443. Washington, DC: U.S. Patent and Trademark Office.

Fu, N., and Chen, X.D. 2011. Towards a maximal cell survival in convective thermal drying processes. Food Research International 44(5): 11271149.

Gabites, J.R., Abrahamson, J., and Winchester, J.A. 2010. Air flow patterns in an industrial milk powder spray dryer. Chemical Engineering Research and Design 88(7): 899-910.

Gardiner, G.E., Bouchier, P., O’Sullivan, E., Kelly, J., Collins, J.K., Fitzgerald, G., and Stanton, C. 2002. A spray-dried culture for probiotic Cheddar cheese manufacture. International Dairy Journal 12(9): 749-756.

Gharsallaoui, A., Roudaut, G., Chambin, O., 
Voilley, A., and Saurel, R. 2007. Applications of spray-drying in microencapsulation of food ingredients: An overview. Food Research International 40(9): 1107 1121.

Hati, S., Das, S., and Mandal, S. 2019. Technological advancement of functional fermented dairy beverages. In Engineering Tools in the Beverage Industry (pp. 101-136). Woodhead Publishing.

Kim, S.S., and Bhowmik, S.R. 1995. Effect of yogurt pre concentration on survival of lactic acid bacteria during drying. Cultured Dairy Products Journal 30(4): 11-18.

Koc, B., Sakin-Y1lmazer, M., KaymakErtekin, F., and Balkır, P. 2014. Physical properties of yoghurt powder produced by spray drying. Journal of Food Science and Technology 51(7): 1377-1383.

Koç, B., Yilmazer, M.S., Balkır, P., and Ertekin, F.K. 2010. Moisture sorption isotherms and storage stability of spray-dried yogurt powder. Drying Technology 28(6): 816-822.

Kothakota, A., Kumar, A., Kumar, M., Juvvi, P., Rao, S., and Kautkar, S. 2014. Characteristics of spray dried dahi powder with maltodextrin as an adjunct. International Journal of Agriculture, Environment and Biotechnology 7(4): 849-865.

Kumar, A., Kumar, P., Nema, P.K., and Sehrawat, R. 2018. Classification of dried milk products. In Novel Dairy Processing Technologies (pp. 117134). Apple Academic Press.

Mahajan B.M., Bhattacharya, D.C., Mathur, O.N., and Srinivasan, M.R. 1979. Production and shelf life of spray dried srikhand powder 16(1): 9-11.

Narayanan, R., and Lingam, J. 2013. Sensory analysis of banana blended shrikhand. African Journal of Agricultural Research 8(44): 55185521.

Písecký, J. 2005. Spray drying in the cheese industry. International Dairy Journal 15(6-9): 531-536.

Santos, G.D., Nogueira, R.I., and Rosenthal, A. 2018. Powdered yoghurt produced by spray drying and freeze drying: A review. Brazilian Journal of Food Technology 21.

Schuck, P., Jeantet, R., Bhandari, B., Chen, X.D., Perrone, Í.T., de Carvalho, A.F., and Kelly, P. 2016. Recent advances in spray drying relevant to the dairy industry: A comprehensive critical review. Drying Technology 34(15): 1773-1790.

Selvamuthukumaran, M., and Shukla, S.S. 2016. Bifidus milk powder: processing parameter standardization and shelf stability evaluation. Journal of Food Science and Technology 53(4): 20542060.

Seshamamba, B.S.V., Bhavya, J.N., Arvind, G., Farzana, S., and Anusha, K. 2016. Production of powdered yoghurt by spray drying. International Journal of Engineering Research 5(05).

Seth, D., Mishra, H.N., and Deka, S.C. (2017b). Functional and reconstitution properties of spray-dried sweetened yogurt powder as influenced by processing conditions. International Journal of Food Properties 20(7): 1603-1611.

Seth, D., Mishra, H.N., and Deka, S.C. (2019). Process Technology of Sweetened Yogurt Powder. In Applied Food Science and Engineering with Industrial Applications (pp. 159-178). Apple Academic Press.

Seth, D., Mishra, H.N., and Deka, S.C. 2017a. Effect of spray drying process conditions on bacteria survival and acetaldehyde retention in sweetened 
yoghurt powder: An optimization study. Journal of Food Process Engineering 40(3): 12487.

Shiby, V K., and Mishra, H.N. 2013. Fermented milks and milk products as functional foods-A review. Critical Reviews in Food Science and Nutrition 53(5): 482-496.

Tamang, J.P., Cotter, P.D., Endo, A., Han, N.S., Kort, R., Liu, S.Q., Mayo, M., Westerik, N. and Hutkins, R. 2020. Fermented foods in a global age: East meets West. Comprehensive Reviews in Food Science and Food Safety 19(1): 184-217.

Teijeiro, M., Pérez, P.F., De Antoni, G.L., and Golowczyc, M.A. 2018. Suitability of kefir powder production using spray drying. Food Research International 112: 169-174.

Wirjantoro, T.I., and Phianmongkhol, A. 2009. The viability of lactic acid bacteria and Bifidobacterium bifidum in yoghurt powder during storage. Journal of Natural Sciences 8(1): 95104.

\section{How to cite this article:}

Kritika Rawat, Anju Kumari, Rakesh Kumar and Partibha. 2020. Spray Dried Fermented Milk Products- A Short Review. Int.J.Curr.Microbiol.App.Sci. 9(07): 1293-1299.

doi: https://doi.org/10.20546/ijcmas.2020.907.148 